\title{
Effects of peptidic growth hormone secretagogue receptor (GHS-R) antagonist [D-Lys3] on some of serum hormonal and biochemical parameters in Wistar rat model
}

\author{
Efeitos do antagonista [D-Lys3] do receptor do peptídeo secretagogo \\ do hormônio do crescimento (GHS-R) sobre alguns parâmetros \\ bioquímicos e hormonais séricos em um modelo em ratos Wistar
}

Habib Aghdam Shahryar' ${ }^{1}$ Alireza Lotfi²

${ }^{1}$ Department of Animal Science, Shabestar Branch, Islamic Azad University, Shabestar, Iran 2 Ilkhchi Branch, Islamic Azad University, Ilkhchi, Iran
Correspondence to: Habib Aghdam Shahryar, Department of Animal Science, Shabestar Branch, Islamic Azad University, Shabestar, Iran ha_shahryar@yahoo.com

\section{ABSTRACT}

Objective: The present study investigated the effects of different dosages of a GHS-R antagonist [D-Lys3] on some serum hormonal (cortisol, $\mathrm{T}_{3}$ and $\mathrm{T}_{4}$ ) and biochemical parameters in a rat. Materials and methods: Thirty-six 60-day-old male rats were assigned to four treatments. [D-Lys3]-GHRP-6 solutions were infused via intraperitoneal injections. Blood was collected and analyzed. Results: The large dosages of a GHS-R antagonist (200 ng/kg BW) caused increases in cortisol, whereas no significant changes occurred when low dosages were injected. There were no significant changes in $\mathrm{T}_{3}$ and $\mathrm{T}_{4}$ following the administration of the GHS-R antagonist, but a considerable increase was observed in blood glucose levels of the groups (G50, G100, and $\mathrm{G} 200 \mathrm{ng} / \mathrm{kg} \mathrm{BW}$ ). There was a significant increase in total protein when the greatest dose was administrated (G200 ng/kg BW). However, total cholesterol, triglycerides, and albumin showed no significant changes. Conclusions: Exogenous GHS-R antagonist can cause an increase in glucose and moderate increases in cortisol and total protein, yet it has no significant effect on $\mathrm{T}_{3}$ and $\mathrm{T}_{4}$ levels or on the concentrations of serum lipids. The effect of GHS-R antagonist is not completely adverse to the effects of ghrelin. Further molecular studies are necessary to identify the physiological effects of the peptidic GHS-R antagonist. Arq Bras Endocrinol Metab. 2014;58(3):288-91

\section{Keywords}

Ghrelin receptor; GHS-R; GH-releasing; regulatory peptide; peripheral infusion

\section{RESUMO}

Objetivo: O presente estudo investigou os efeitos de diferentes doses do antagonista do GHS-R [D-Lys3] sobre alguns parâmetros hormonais (cortisol, $\mathrm{T}_{3} \mathrm{eT}_{4}$ ) e bioquímicos em ratos. Materiais e métodos: Trinta e seis ratos machos com 60 dias de idade foram alocados para quatro tratamentos. Soluções de [D-Lys3]-GHRP-6 foram administradas por meio de injeções intraperitoneais e foram coletadas e analisadas amostras. Resultados: Doses altas de antagonista de GHS$-R(200 \mathrm{ng} / \mathrm{kg} \mathrm{PC}$ ) levaram a aumento do cortisol, enquanto não houve diferença significativa quando foram injetadas doses baixas. Não houve alterações significativas em $\mathrm{T}_{3} \mathrm{eT}_{4}$ depois da administração do antagonista do GHS-R, mas foi observado aumento considerável nos níveis de glicose sanguínea dos grupos (G50, G100 e G200 ng/kg PC). Houve aumento significativo na proteína total quando foi administrada a maior dose (G200 ng/kg PC), entretanto, não foram observadas alterações no colesterol total, nos triglicérides e na albumina. Conclusões: 0 antagonista do GHS-R exógeno pode causar aumento da glicose e aumento moderado do cortisol e proteína total, embora não haja efeitos significativos nos níveis de $\mathrm{T}_{3} \mathrm{eT}_{4}$ ou na concentração de lipídios séricos. $\mathrm{O}$ efeito do antagonista de GHS-R não é completamente adverso aos efeitos da grelina. Devem ser feitos outros estudos moleculares para se identificar os efeitos fisiológicos do peptídeo antagonista do GHS-R. Arq Bras Endocrinol Metab. 2014;58(3):288-91

Descritores

Receptor da grelina, GHS-R, liberação de GH, peptídeo regulador, infusão periférica 


\section{INTRODUCTION}

The growth hormone secretagogue receptor (GHS-R) is a $\mathrm{G}$ protein-coupled receptor that binds with ghrelin. It plays an important role in energy homeostasis, metabolism, and regulation of body weight $(1,2)$.

Ghrelin receptors can bind with GHS-R antagonists and block them. GHS-R antagonists can be created by manipulating related peptides. For example, a minor change in GHRP-6 (a GH-releasing peptide) by replacing D-lysine with alanine can change the GHS specificity of GHRP-6, and create a new biomolecule with antagonist effects on GHS-R (3). A synthetic peptidic, ghrelin antagonist [D-Lys3] GHRP-6 (HisDTrp-DLys-Trp- DPhe-Lys-NH2) (Figure 1) is widely utilized in vivo and in vitro as the preferred ghrelin receptor $(3,4)$.

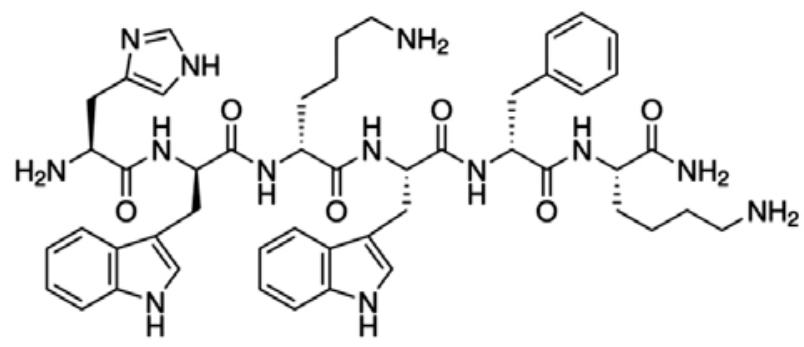

Figure 1. Chemical structure of D-Lys3-GHRP-6.

Ghrelin was identified as the strongest GH-stimulator peptide (5). Today, almost all significant endocrine effects of ghrelin as a GH-, PRL- or ACTH-releasing peptide are identified (5-8). It was proposed that if ghrelin is an endocrine peptide and has numerous endocrine effects, blocking its receptors may change the endocrine and metabolic profile of the body. To test this theory, different dosages of GHS-R antagonist [DLys3] were peripherally injected into laboratory rats.

\section{MATERIALS AND METHODS}

This experiment was conducted in the animal room of the Islamic Azad University in 2012. Thirty-six 60-dayold male rats were assigned to 4 treatments and 3 replicates (with 3 animals) in each treatment. The experiment was arranged in a completely randomized design (CRD). The study was conducted in compliance with the Animal Welfare Act, and in accordance with ethical rules of Islamic Azad University.

\section{Injection procedure and sampling}

[D-Lys3]-GHRP-6 lyophilized powder (Sigma-Aldrich, USA) was dissolved in distilled water according to the manufacturer's instructions. The prepared solution was infused via intraperitoneal injections. After 48 $\mathrm{h}$, blood samples were taken collected from the heart following anesthesia.

\section{Analysis}

Blood samples were centrifuged $(1,200 \mathrm{X} \mathrm{g}, 7 \mathrm{~min}$, $18^{\circ} \mathrm{C}$ ), and serum was prepared with Alcyon 300 auto analyzer (Abbott Park, IL, USA) and its commercial kits (Elisa Pars Azmoon kits, Pars Azmoon Inc., Tehran, for the biochemical assay, and Glory Elisa kits, USA, for the hormonal assay) in order to determine the values of blood biochemical (glucose, total cholesterol, triglycerides, HDL-cholesterol, albumen, total protein) and hormonal parameters (cortisol, $\mathrm{T}_{3}$, and $\mathrm{T}_{4}$ ). Data from the experiment was evaluated with the SAS software (SAS Inst. Inc., Cary, NC), and the differences between treatments were investigated by Tukey test with $P<0.05$ being considered significant.

\section{RESULTS AND DISCUSSION}

The administration of great doses of the GHS-R antagonist (200 ng/ $\mathrm{kg} \mathrm{BW}$ ) caused cortisol increases in rat serum, whereas no significant changes occurred when low dosages were injected (Table 1 ). There were no significant changes in $\mathrm{T}_{3}$ and $\mathrm{T}_{4}$ hormones following the administration of the GHS-R antagonist (Table 1 ).

As seen in table 2, there was a significant increase in blood glucose for groups submitted the administration of the GHS-R antagonist (G50, G100, and G200). A significant increase in total protein was observed when the greatest dose was administrated (G200), whereas total cholesterol, triglycerides, and albumin showed no significant changes (Table 2).

Table 1. Serum hormonal parameters in rats following peripheral administration of GHS-R antagonist

\begin{tabular}{|c|c|c|c|}
\hline Group Variable & $\begin{array}{l}\text { cortisol } \\
\mu \mathrm{g} / \mathrm{mL}\end{array}$ & $\begin{array}{c}\mathrm{T}_{3} \\
\mathrm{ng} / \mathrm{mL}\end{array}$ & $\underset{\mu g / m L}{T_{4}}$ \\
\hline G0 (Control) (0 ng/kg) & $1.36 \pm 0.05^{b}$ & $0.90 \pm 0.16$ & $9.80 \pm 0.49$ \\
\hline G50 (50 ng/kg) & $1.37 \pm 0.07^{b}$ & $0.97 \pm 0.20$ & $9.43 \pm 0.25$ \\
\hline G100 (100 ng/kg) & $1.43 \pm 0.05^{b}$ & $1.17 \pm 0.25$ & $9.10 \pm 0.45$ \\
\hline G200 (200 ng/kg) & $1.88 \pm 0.06^{a}$ & $1.13 \pm 0.19$ & $9.97 \pm 0.41$ \\
\hline$P$ value & $<0.0001$ & 0.088 & 0.218 \\
\hline
\end{tabular}

Different letters (a or b) show significant difference between means. 
Table 2. Serum biochemical parameters in rats following peripheral administration of GHS-R antagonist

\begin{tabular}{|c|c|c|c|c|c|c|}
\hline Group Variable & $\begin{array}{l}\text { Glucose } \\
\mathrm{mg} / \mathrm{mL}\end{array}$ & $\begin{array}{l}\text { Total cholesterol } \\
\mathrm{mg} / \mathrm{mL}\end{array}$ & $\begin{array}{l}\text { Triglyceride } \\
\mathrm{mg} / \mathrm{mL}\end{array}$ & $\begin{array}{l}\text { HDL-cholestrol } \\
\mathrm{mg} / \mathrm{mL}\end{array}$ & $\begin{array}{l}\text { Albumin } \\
\mathrm{mg} / \mathrm{mL}\end{array}$ & $\begin{array}{l}\text { Total protein } \\
\mathrm{mg} / \mathrm{mL}\end{array}$ \\
\hline G0 (Control) (0 ng/kg) & $145.0 \pm 9.32^{\mathrm{b}}$ & $85.0 \pm 4.08$ & $40.0 \pm 3.54$ & $28.5 \pm 2.18$ & $3.23 \pm 0.11$ & $8.27 \pm 0.25^{b}$ \\
\hline G50 (50 ng/kg) & $172.3 \pm 10.02^{\mathrm{a}}$ & $82.3 \pm 4.00$ & $41.0 \pm 4.00$ & $30.0 \pm 5.12$ & $3.67 \pm 0.08$ & $7.73 \pm 0.20^{b}$ \\
\hline G100 (100 ng/kg) & $188.0 \pm 8.81^{\mathrm{a}}$ & $83.0 \pm 3.78$ & $41.1 \pm 4.41$ & $31.0 \pm 2.40$ & $3.30 \pm 0.12$ & $7.90 \pm 0.17^{b}$ \\
\hline G200 (200 ng/kg) & $179.4 \pm 9.00^{\mathrm{a}}$ & $84.2 \pm 3.79$ & $40.7 \pm 3.08$ & $29.4 \pm 2.10$ & $3.53 \pm 0.19$ & $8.97 \pm 0.31^{\mathrm{a}}$ \\
\hline$P$ value & 0.002 & 0.848 & 0.982 & 0.079 & 0.069 & 0.002 \\
\hline
\end{tabular}

Different letters (a or b) show significant difference between means.

One study showed that the administration of a ghrelin agonist (growth hormone releasing peptide-2) caused transient increases in serum cortisol (9). Wagner and cols. (10) showed that the administration of synthetic somatostatin (growth hormone-inhibiting hormone) caused an elevation in serum cortisol levels. In published studies, there was no direct evidence of the stimulatory effect of the GHS-R antagonist on the release of glucocorticoids. The regulatory effect of ghrelin on glucocorticoids is well documented $(11,12)$, although the infusion of ghrelin is not able to cause hypercortisolemia (11). In the present study, it seemed that the infusion of greater dosages of the GHS-R antagonist induced a GH-deficient condition, and subsequent increase in cortisol, similar to the study by Wagner and cols. (10). On the other hand, ghrelin receptor blockage and the lack of ghrelin effect, as regulatory factors in the release of glucocorticoid, cause a change in cortisol levels (Table 1). Increases in serum glucose in groups submitted to GHS-R antagonist infusion can be the result of cortisol increases (Tables 1 and 2). Chacko and cols. (13) stated that gluconeogenesis and glycogenolysis are increased and insulin sensitivity is improved by the ablation of the ghrelin or growth hormone secretagogue receptor. Ghrelin is a key peptide in the caloric stability of the body and can maintain glucose homeostasis (14). In this regard, it was reported that glucose or insulin at physiological concentrations cannot efficiently affect the regulation of ghrelin plasma concentrations. In the present findings, the administration of the GHS-R antagonist caused an increase in serum glucose along with significant increases in total protein (Table 2). Therefore, it is suggested that the body can consume more protein resources for glucose synthesis in ghrelin-deficient conditions induced by the infusion of the GHS-R antagonist. In this regard, Khazali (15) stated that, in energy deficient conditions, ghrelin can trigger more protein catabolism as energy sources and increase peripheral urea.
In conclusion, the peripheral administration of GHS-R can cause an increase in glucose levels and moderate increases in cortisol and total protein rates with no significant effect on $\mathrm{T}_{3}$ and $\mathrm{T}_{4}$ levels or on the concentration of serum lipids. The effect of the GHS-R antagonist is not completely adverse to the ghrelin effect, but it seems that it can moderate the regulatory effect of ghrelin on glucocorticoids and glucose metabolism. The present study investigated numerous serum endocrine and biochemical parameters, but supplementary and comparative molecular studies are necessary for the identification of the physiological effects of the peptidic GHS-R antagonist.

Acknowledgments: the authors are thankful to Dr. A. Karami Bonary for his assistance in laboratory analyses.

Disclosure: no potential conflict of interest relevant to this article was reported.

\section{REFERENCES}

1. Smith RG, Leonard R, Bailey AR, Palyha O, Feighner S, Tan C, et al. Growth hormone secretagogue receptor family members and ligands. Endocrine. 2001;14(1):9-14.

2. Petersenn S. Structure and regulation of the growth hormone secretagogue receptor. Minerva Endocrinol. 2003;27(4):243-56.

3. Smith R, Cheng K, Schoen W, Pong S, Hickey G, Jacks T, et al. A nonpeptidyl growth hormone secretagogue. Science. 1993;260:1640-13.

4. Patel K, Dixit VD, Lee JH, Kim JW, Schaffer EM, Nguyen D, et al. Identification of ghrelin receptor blocker, D-[Lys3] GHRP-6 as a CXCR4 receptor antagonist. Int J Biol Sci. 2012;8(1):108-17.

5. Kojima M, Hosoda H, Date Y, Nakazato M, Matsuo H, Kangawa K. Ghrelin is a growth-hormone-releasing acylated peptide from stomach. Nature. 402;1999:656-60.

6. Kaiya H, Kojima M, Hosoda H, Riley LG, Hirano T, Grau EG, et al. Identification of tilapia ghrelin and its effects on growth hormone and prolactin release in the tilapia, Oreochromis mossambicus. Comp Biochem Physiol B Biochem Mol Biol. 2003;135(3):421-9.

7. Lotfi A, Shahryar HA, Ghale-Kandi JG, Kaiya H, Ahmadzadeh A. In ovo administration of ghrelin and subsequent prolactin level in newly hatched chicks. J Poult Sci. 2011;48:135-7.

8. Pecori Giraldi F, Bucciarelli LG, Saccani A, Scacchi M, Pesce S, Losa $\mathrm{M}$, et al. Ghrelin stimulates adrenocorticotrophic hormone 
(ACTH) secretion by human ACTH-secreting pituitary adenomas in vitro. J Neuroendocrinol. 2007;19(3):208-12.

9. Laferrère $B, C y n t h i a A$, Colleen DR, CyrilYB. Growth hormone releasing peptide-2 (GHRP-2), like ghrelin, increases food intake in healthy men. J Clin Endocrinol Metab. 2005;90(2):611-4.

10. Wagner $\mathrm{H}$, Zierden $\mathrm{E}$, Hauss WH. Effects of synthetic somatostatin on endotoxin-induced changes of growth hormone, cortisol and insulin in plasma, blood sugar and blood leukocytes in man. Klin Wochenschr. 1975;53(11):539-41.

11. Ghigo E. Ghrelin. In chapter 1: Historical milestones. 1st edition. Boston: Kluwer Academic Publishers; 2004. p. 7.

12. Martínez-Fuentes AJ, Moreno-Fernández J, Vázquez-Martínez $R$, Durán-Prado $M$, de la Riva A, Tena-Sempere $M$, et al. Ghrelin is produced by and directly activates corticotrope cells from adrenocorticotropin-secreting adenomas. J Clin Endocrinol Metab. 2006;91(6):2225-31.

13. Chacko SK, Haymond MW, Sun Y, Marini JC, Sauer PJ, Ma X, et al. Effect of ghrelin on glucose regulation in mice. Am J Physiol Endocrinol Metab. 2012;302(9):E1055-62.

14. Briggs DI, Andrews ZB. A recent update on the role of ghrelin in glucose homeostasis. Curr Diabetes Rev. 2011;7(3):201-7.

15. Khazali $H$. Third ventricle ghrelin infusion effect on the metabolic parameters under different energy levels in diets. Iranian J Sci Tech Trans A. 2009;33:31-42. 